\title{
A typology of media innovations: Insights from an exploratory study
}

\author{
Valérie-Anne Bleyen, Sven Lindmark, Heritiana Ranaivoson and Pieter Ballon \\ IMinds/SMIT - Vrije University of Brussel. \\ Corresponding author: Valerie-Anne.Bleyen@vub.ac.be
}

\begin{abstract}
The concept and phenomenon of media innovation is gaining some attention in the academic community, policy circles and among practitioners. However, the phenomenon is still poorly defined and not well understood. This paper therefore first analyses how media innovation is framed in the literature on media economics and media management. Then it considers to what extent the standard analysis of innovation could be applied to the media field, considering, on the one hand, the traditional view on innovation policy and, on the other hand, some of the most common indicators of innovation. Based on this information, the paper suggests a novel conceptualisation of media innovation.

Furthermore, an analysis of statistical indicators on R\&D expenditure leads to three assumptions related to media innovation, namely (1) that the Media and Content Industries (MCIs) are much less innovative than the ICT industries, or/and (2) that R\&D statistics do not properly capture the innovativeness of the MCIs, or/and (3) that the innovative activities in media and content are largely taking place elsewhere (for instance in the ICT sector). Whereas the statistical indicators point towards the second explanation, a small round of expert interviews in Flanders revealed that there is a case for assumptions (1) and (3) as well. First of all, it was shown that all forms of innovation defined in our typology exist in the media field, but not with the same importance. The most important ones from the media industries' point of view seems to be the innovation related to the product, notably concerning the core (e.g. creation of new types of TV shows) and business model innovation. There is also technological innovation taking place in the media industries, for instance
\end{abstract}

The Journal of Media Innovations 1.1 (2014): 28-51

(C) Valérie-Anne Bleyen, Sven Lindmark, Heritiana Ranaivoson and Pieter Ballon 2014 http://www.journals.uio.no/index.php/TJMI 
concerning new ways to access and interact with the content but this innovation comes from out the media sector (e.g. HD-TV, search engines) and at best the media industries try to adapt to this rapidly changing technological context.

\section{Introduction}

It is well known that innovation is an important driver of economic growth, competitiveness and progress of businesses and countries alike (European Commission [EC], 2010). It transforms industries in processes of 'creative destruction' (Schumpeter, 1942), allowing for new entrepreneurial companies to enter the market; for existing ones to grow and enhance their competitive positions. At the same time innovation challenges incumbent players, sometimes in a disruptive way destroying companies and entire industries.

The media industry is no exception; all over the world media companies are in flux. Boundaries between sectors are increasingly becoming blurred, and new coopetition patterns emerge. This transformation has been largely driven by digitisation, where various types of digitally created content are aggregated and distributed over a multitude of digital distribution channels and devices to consumers. This triggers interaction between previously fairly disconnected players in the market and shifts power balances, within and across previously distinct value networks (e.g. EU Media Futures Forum (2012); IPTS (2012)). Digitisation thus brings about a reconfiguration of both the value network and revenue flows in the media and content industries, in turn leading to uncertainty, conflicts and strategic shifts in the new media ecosystem. Innovation is imperative for media companies to cope with such dynamic shifts. Established players need to proactively innovate and not only protect the core business of today. Similarly, policies are needed to support innovation, and such policies need to be grounded in and evaluated based on monitoring and analysis of proper indicators.

However, innovation in media is not well understood; it seems to be ill defined and poorly captured by statistics. Different players in the industry have different views on what innovation actually is, whether they are involved in innovation at all, and whether they should be (Donders et al., 2011). At a macroeconomic level (i.e. "How much innovation is there in the media sector?"), it results in the persistent debate, between those who claim the media industry's lack of emphasis on innovation and those who argue that innovation is present in the media firms' everyday activity (see in particular Küng's (2008) analysis). Also at policy level, media innovation is ambiguously addressed. On the one hand, media innovation receives less attention in innovation policy, in Europe and elsewhere, than it perhaps deserves. This is partly because large parts of the creative activity that take place in the media and content sector remain 'under the radar' since they are not defined as being innovation. On the other hand, media 
policies are more concerned with issues such as pluralism, diversity, localism, copyright, etc. Therefore they traditionally do not frame their policies in terms of innovation.

To shed light on the above issues, this paper explores the concept of media innovation. It uses different approaches to do so, and its main contribution derives from the original combination of points of view. First it analyses how media innovation is framed in the literature on media economics and media management. Then it considers to what extent the standard analysis of innovation could be applied to the media field, considering, on the one hand, the traditional view on innovation policy and, on the other hand, some of the most common indicators of innovation. Based on this information, the paper suggests a novel conceptualisation of media innovation. Furthermore, an analysis of statistical indicators on $R \& D$ expenditure leads to three assumptions related to media innovation, namely (1) that the Media and Content Industries (MCIs) are much less innovative than the ICT industries, or/and (2) that R\&D statistics do not properly capture the innovativeness of the MCIs, or/and (3) that the innovative activities in media and content are largely taking place elsewhere (for instance in the ICT sector). Whereas the statistical indicators point towards the second explanation, a small round of expert interviews in Flanders revealed that there is a case for assumptions (1) and (3) as well.

This paper is structured as follows. The second section addresses the concept of innovation, reviews received conceptualisations of media innovation and how they are captured by indicators. It then proposes a self-designed framework for how to conceptualise media innovation. The third section explores the role of media innovation in innovation policy. It also provides a statistical data analysis on innovation indicators captured by $R \& D$ expenditures. Consequently, in the fourth section a small-scale empirical exploration based on expert interviews with representatives from three media sectors (daily press, magazine and audiovisual) is provided. The fifth section concludes with implications for further research.

\section{Media Innovation: Definitions and Typology}

\section{The Specificities of Media Innovation}

Innovation is a broad concept both in theoretical terms and in actual policy practice. In general, scholars agree that innovation concerns the introduction of something new with an element of valorisation (or utilisation) to it (Schumpeter, 1942; Organisation for Economic Co-operation and Development [OECD], 2005). In other words, innovation involves putting an invention into practical use. Although conceptually simple, all parts of the definition require some careful 
delineation: (1) what is meant by new; (2) what is the object of novelty (product, process, etc.); and (3) what is meant by putting into practical use?

Firstly, there is the dimension of novelty. What is genuinely new and what is in fact a modification of something that already exists? The issue of novelty in general relates to how radical the change is compared to existing practices (e.g. Freeman and Soete, 1997), i.e. one may distinguish between discontinuous (or radical) and continuous (or marginal) innovation. Another distinction is between innovators (who for the first time introduces the innovation) and imitators (who introduces the same innovation in a different context). In the media field, distinctions have been made between real innovations, quasi-new products and me-too products (Köhler, 2005); and whether newness applies to (1) all other organisations at either the global or (2) the local level or (3) the organisation itself (Castañer \& Campos, 2002). A further issue here is that novelty is multidimensional, which makes it difficult to measure the degree of novelty (Kamprath \& Mietzner, 2009). According to Kamprath and Mietzner (2009), radical innovations are characterised by how they influence demand patterns (market), often through new technology, while exerting significant influence on both the innovator (organisation) and on the industry (or even society) as a whole (environment).

Secondly, while this discussion on novelty is not specific to media innovation, what the novelty concerns (e.g. a new product, service, process, business model, content, format), becomes pertinent and all the more particular for the media industries. Traditionally, the innovation literature studies innovation as the creation of value via the introduction of new products, processes, services, new ways of organising businesses ('business model innovation' or 'organisational innovation') or - more generally - new ways of doing things.

However, most innovation definitions either explicitly or implicitly do not consider new content (e.g. a new movie, news item, or song, etc.). The OECD provides guidelines for collecting data on innovation in its Oslo manual (OECD, 1997; OECD, 2005). Up until the second edition (OECD, 1997) the manual dealt solely with technological product and process (TPP) innovation, and explicitly excluded "creative product improvement" (OECD, 1997, p.39) and changes in aesthetic or other subjective qualities (p.37), mainly because such improvement did not concern their "essential characteristics or performance" (p.39). The most recent edition of the manual (OECD, 2005) broadens the innovation concept from TPP to any "implementation of a new or significantly improved product (good or service), or process, a new marketing method, or a new organizational method in business practices, workplace organization or external relations" (OECD, 2005, p.46). Still, there is no explicit mention of creative innovation with product innovation defined as the "introduction of a good or service that is new or significantly improved with respect to its characteristics or intended uses. This includes significant improvements in technical specifications, components and materials, incorporated software, user friendliness or other functional 
characteristics" (OECD, 2005, p.46). Similarly, the definition of R\&D (OECD, 2002), although referring to $R \& D$ as being creative work, fails to mention creative product development as being part of $R \& D$ activity. In fact, only activities that resolve scientific and/or technological uncertainties are included (OECD, 2002, p.34). Therefore it implicitly excludes content innovation related activities.

It can thus be argued that traditional definitions (and indicators) overlook creative activities that lead to aesthetic, educational and entertainment renewal, and which may have substantial socio-economic impacts. A related point was also made by Küng (2008), who states that "while clearly distinguished in academic literature, in practice creativity and innovation are hard to disentangle within the media industry" (p.11). This paper argues that there is a case for broadening the concept of innovation to include also content-related novelties A few attempts have already been made in this direction in the literature, as will be shown in the following (see also Dogruel (2013) for an overview).

Stoneman (2010) introduced the notion of "soft innovation" (see also NESTA, 2009b), i.e. innovation that primarily impacts aesthetic and intellectual appeal, not technical functionality. He makes the case that a significant part of the workforce is involved in soft innovative activities both inside and outside the creative industries, and that such innovations have a significant and increasing impact. Stoneman (2010) notes that soft innovation is not properly captured by R\&D and innovation definitions. He additionally points out that soft innovation is increasing and that creative industries are more innovative that non-creative ones.

Along similar lines, Jaanieste (2009) points out that TPP innovation - the traditional focus of innovation policy - needs to be complemented with "Cultural Product and Process (CPP) innovation", i.e. research, development, application and diffusion of cultural products (stylistic changes, changes to forms, changes to content) and their processes (the ways such products are made, delivered and distributed).

Originally coined in the 1990s, the concept of "hidden innovation" has more recently been popularised by NESTA in their "Innovation Gap" (NESTA, 2006) and "Hidden innovation" (NESTA, 2007) reports. Hidden innovations are innovation activities that are not properly recognised because of inadequate measurements. Based on an analysis of service innovation, Abreu et al. (2010) show that innovation activities are underestimated when metrics of R\&D and patents are applied. Hidden innovation includes: (1) innovation that is the same or similar to activities that are measured by traditional indicators, but which is excluded from measurement; (2) innovation without a major scientific/technological basis, such as innovation in organisational forms or business models, (3) innovation created from the novel combination of existing technologies and processes, (4) locally-developed, small-scale innovations that take place 'under the radar' and are therefore unrecognised or unaccounted for. 
Reasoning among these lines, media innovation can be claimed to be "hidden" as well.

Handke (2010) further argues that technological definitions of innovation are problematic when it comes to the cultural industries and that it is particularly important to incorporate aesthetic changes in order to come to an adequate assessment of innovation as determinant of competitiveness. Drawing on Caves' (2000) notions of creative and humdrum input, Handke (2010) proposes to make the distinction between "humdrum innovation" that regards media technologies and the marketing of cultural products, and "creative innovation". While both types are likely to occur simultaneously (often in the same firms) in the media industries, they are important to measure separately. In a related way, Roberts (2010) distinguishes innovation as it relates to content or goes beyond content.

Hence there seem to be several arguments for a broadening of what is the object referred to by the concept of novelty, in order to capture "soft" and "hidden" cultural innovations. However, applying a too broad definition of innovation in media can also be problematic. Any creative product (apart from pure duplication) could be defined as an innovation (e.g. any new film, any newspaper article, song, video game, etc.). Media innovations need to be distinguished from routinely produced media products (Dogruel, 2013).

Finally, the innovation requires to be put in practical use. Implicitly the requirement is quantitative, i.e. if only one person adopts something, it cannot be considered as an innovation. Küng (2008) explicitly refers to an innovation as something that has to be "successful" in its implementation (p.5). Furthermore, to "put in practical use" implies that a process perspective on innovation is needed. Innovation is not only an output, but also the process that includes exploration and development as well as exploitation, commercialisation and diffusion. Earlier, this process was often seen as linear, starting out with basic research, and then moving via applied research, development and production to the market. Such views have been replaced by more complex views on innovation, such as the chain-linked model of innovation (Kline \& Rosenberg, 1986) where innovation is seen as based on processes of interaction and feedback, in which the object of innovation constantly changes.

\section{Towards a Typology of Media Innovation}

A review of the literature on innovation definitions brings us to the question of how a typology can be developed that encompasses media innovation and goes beyond (but builds on) the traditional product/process based innovation. Scholars have traditionally distinguished product and process innovation (e.g. Schmookler, 1966; Cave \& Frinking, 2007) but, as pointed out below, this distinction can be difficult in the case of media. 
Here, one may then say that product innovation relates to all innovation concerning content (with a possible distinction between the core - i.e. the theme, the message - and the inner form - i.e. the style) and the outer form - i.e. the way it is accessed by customers (Schweitzer, 2003). For instance, a new format (e.g. reality-TV) is an innovation in the core; the special effects in Avatar are an innovation in terms of inner form; a new medium like the Blu-ray format is an innovation in the outer form. In general, any innovation related to content corresponds to what Stoneman (2010) refers to as "soft innovation". This is on the other hand slightly contradictory with the view, expressed e.g. by Küng (2008) that a new idea relates to creativity rather than to innovation.

In the case of process innovation, it is worth considering a production process in the form of a value chain. A process innovation is an innovation that relates to one or several of the following steps:

- Creation (e.g. a new camera);

- $\quad(\mathrm{Re})$ production (e.g. a new video codec);

- Aggregation (e.g. a new encoding format);

- Distribution (e.g. use of the Internet to distribute audiovisual content);

- Exhibition (e.g. 3D cinema) and;

- Consumption (e.g. possibility to choose which camera is followed during a sport event).

A last form of process innovation, "business model innovation", is difficult to grasp through the above decomposition of the production process as it corresponds to an innovation in the organisation of the industry itself. This includes the entrance in new markets, the building of alliances, the modification in one firm's market situation, etc. - as long as it can be considered as innovative. More generally this includes any successful new feature of a business model1 with the exception of the innovation processes that are directly related to one of the steps of the value chain identified in the previous paragraph.

Based on the above, we propose a typology of innovation in the media sector, which summarises the distinctions made before and suggests in addition some groupings in order to restrain the number of categories (see Table 1). This categorisation aims to be synthetic and considers the close links and interdependencies that can be found between product and process innovation, and content, organisational and technological innovation.

The typology takes as a starting point the standard distinction between product and process innovation, which is also reflected in the distinction made by Handke (2010) between creative and humdrum innovations. Within product

\footnotetext{
${ }^{1}$ For an overview of the theory on business models, see Ballon (2007).

2 The following stakeholders were consulted: (1) European Magazine Media Association (EMMA); (2) Vlaamse Nieuwsmedia and (3) Acht TV. EMMA is a non-profit
} 
innovation, content innovation is categorised into core and inner form innovation, while process innovation is divided into production and distribution innovation and business model innovation. Within the former, creation, (re)production, aggregation, distribution and exhibition were grouped because they all concern process innovations, which generally have a source in a firm and are not perceptible by the consumers. In contrast, innovations in business models often concern several firms if not an entire ecosystem of firms. In addition, they are more global and not related to one step of the value chain.

The main contribution of the typology is the fact that it identifies a fifth category of innovation - Consumption and media innovation - as situated between process and product innovation. This category includes all innovations related to consumption and media. On the one hand it deals with how the product is marketed and made available to the consumer. On the other hand it is often directly linked to the product itself and most of all it is perceptible by the consumer and not separable in terms of consumer experience. This is for example the case with all developments in second screen applications. They have an impact on, on the one hand, how content is being introduced (notably to allow for more interaction) and, on the other hand, how viewers perceive the program (notably since they are in a more active posture).

Table 1

A typology of media innovations

\begin{tabular}{|c|c|c|c|c|}
\hline \multicolumn{2}{|l|}{ Process } & \multicolumn{3}{|c|}{ Product } \\
\hline Business Model & $\begin{array}{l}\text { Production \& } \\
\text { Distribution }\end{array}$ & $\begin{array}{l}\text { Consumption \& } \\
\text { Media }\end{array}$ & Inner form & Core \\
\hline $\begin{array}{l}\text { A new feature of a } \\
\text { business model, } \\
\text { including a new } \\
\text { organisation of an } \\
\text { industry }\end{array}$ & $\begin{array}{l}\text { A new means of creating, } \\
\text { producing, reproducing, } \\
\text { distributing or marketing } \\
\text { a content }\end{array}$ & $\begin{array}{l}\text { A new way of } \\
\text { consuming a } \\
\text { content, or a } \\
\text { related service }\end{array}$ & $\begin{array}{l}\text { A new } \\
\text { stylistic } \\
\text { feature }\end{array}$ & $\begin{array}{l}\text { A new } \\
\text { theme } \\
\text { or } \\
\text { message }\end{array}$ \\
\hline
\end{tabular}

While the typology covers innovations appearing across the supply side, there are two main limitations. First, innovations coming from the user side are not entirely covered. Thus the "Consumption \& Media" innovations are innovations on how media is consumed, but such innovations are designed by companies while there can also be innovations coming from the audience. Second, the typology leaves aside typologies of innovation based on the degree of novelty of the innovation like Kamprath and Mietzner (2009); or Martin's (2009) innovation funnel that distinguishes between hunches (based on implicit knowledge and hardly replicable), heuristics (based on explicit knowledge but hardly replicable) and algorithms (clearly identified and to some extent replicable). 


\section{How Standard Approaches to Innovation Fail in the Case of Media}

Standard literature on innovation has proved useful to build the typology of media innovations (cf. supra), although it indeed had to take into account the media sector's specificities, in particular the role of content-related innovation. This section shows that on the contrary, traditional approaches to innovation policy and economic assessment of the degree of innovation of an economic sector do not work really well to understand the innovation that is taking place in the media.

\section{Technological Bias of Innovation Policy and Its Limited Application to Media}

According to Lundvall and Borrás (2005), the main objective of innovation policy is typically to boost economic growth and international competitiveness, while also addressing problems related to social cohesion and equality, the environment, etc. Innovation policy typically implies a broad range of initiatives related to Intellectual Property Rights (IPR) and access to venture capital as well as reforms of universities, education, capital markets, regulated industries and competition laws.

Innovation policy can be seen as having emerged in the $1970 \mathrm{~s}$, from the earlier policy paradigms of science policy (support of universities, technological institutes and R\&D labs) and technology policy (instrumental focus on national prestige and economic objectives, strategic sectors, national champions, national and European technologies). Innovation policy has focused on creating, on the one hand, the right framework conditions (in order to remedy market failures), and, on the other hand, the right systemic conditions, focusing on strengthening linkages between parts of innovation systems (to remedy systemic failures) (Lundvall \& Borrás, 2005).

As a consequence of how it emerged, innovation policy has since long been based around scientific knowledge and manufactured technologies, and hence biased to what Jaaniste (2009) calls the STEM sector (as in Science, Technology, Engineering and Mathematics). Although innovation policy has increasingly taken on aspects of other policies; science and technology have remained at its core (NESTA, 2006).

In recent years, the concept of 'innovation policy mix' has become increasingly popular as a way of thinking about the balance and coherence of the strategic task for policy and the range of policy instruments deployed (OECD, 2010). Ideally, the task of innovation policy makers is to find and implement an 'optimal' policy mix that takes into account interactions between policy instruments and ensures a balanced support for the challenges that the innovation systems face. Key for evaluating the policy mix is to ask whether or not the mix 
is appropriate, efficient and effective, and how to design new ones. The increasing recognition of the complexity of what determines innovation leads to larger numbers of possible tools to address innovation, while at the same time, innovation policy competencies (and hence instruments) can be found at international, national as well as sub-national level. The levels need to be coordinated, but such 'multi-level governance' tends to be underdeveloped. The growing interest in the concept of innovation policy mix reflects recognition of these complexities (OECD, 2010).

The scope of innovation policy can be related first to the different rationales (market failure and system failure) and the ultimate goals and strategic tasks of policy, in turn derived from a diagnosis of a state of the system. While the goals could be e.g. to foster economic growth, improve well-being; strategic tasks could be issues such as unleashing the innovation potential of firms, promote innovation in governments, enhance contribution of public research, provide supportive infrastructures, ensure proper valuation of knowledge, and to engage educated people. Finally, policy instruments are influenced by different goals and strategic tasks, but also by different political and socio-economic circumstances (OECD, 2010). These are often categorised as being either demand-side or supply-side measures (OECD, 2010, p.260).

Traditionally, innovation policy and policy towards media industries have been fairly disconnected. Starting around the turn of the millennium, a more active early creative sector discourse began to directly address innovation policy (Jaaniste, 2009). Still, according to Jaaniste (2009), with the exception of the UK's 'Innovation Nation' policy by the mid 2000s, most innovation policies were mainly concerned with STEM-based innovations. The disconnection is even more visible since it can be argued, following Roberts (2010), that the focus of innovation research applied to media "has been almost exclusively on content, to the almost total exclusion of innovation in other areas and activities" (p.13).

\section{The Debatable Level of Innovation in the Media Industries}

The most commonly available indicator for innovation is R\&D expenditures, more specifically Business Expenditures on Research and Development (BERD). Statistics are available at country and sub-sectoral levels on a yearly basis. For the purposes of collecting statistics, OECD (2009) provided an official definition of what constitutes the 'Media and Content Industries' (MCI). These are defined as "industries that are engaged in the production, publishing and/or the distribution of information, cultural and entertainment products, i.e. goods and services which are primarily intended to inform, educate and/or entertain humans through mass communication media" (OECD, 2009). In practice, this definition includes companies with activities related to publishing, motion picture, sound recording, radio and television broadcastings, and information services. 
Data on BERD in the EU-27 (Table 2) for 2009 shows that R\&D expenditures are low for the MCI, in absolute value as well as relative to the Value Added. The difference is particularly striking when comparing with the ICT sector where R\&D intensity is more than ten times higher than for MCI $(5.3 \%$, resp. $0.4 \%$; see Table 2). This suggests that (1) the MCIs are much less innovative than the ICT industries, or/and (2) R\&D statistics do not properly capture the innovativeness of the MCIs, or/and (3) the innovative activities in media and content are largely taking place elsewhere (for instance in the ICT sector). The previous analysis of media innovation, in particular the fact that content innovation is largely dismissed by the standard approach to innovation, would go in the second explanation that $R \& D$ statistics do not properly capture the innovativeness of the MCIs. However, assumptions (1) and (3) still need to be addressed.

Table 2 Official R\&D statistics for MCI, ICT and total industry (EU-27, 2009) (Source: Eurostat SBS and BERD data (2009); Stancik \& Desruelle (2012))

\begin{tabular}{|c|l|l|l|}
\hline & MCI & ICT & All sectors \\
\hline BERD (€ Bn) & 0.4 & 25 & 146 \\
\hline $\begin{array}{c}\text { Value Added } \\
(\text { VA) (€ Bn) }\end{array}$ & 100 & 470 & $12000(\mathrm{ca})$ \\
\hline $\begin{array}{c}\text { R\&D intensity } \\
(\text { BERD/VA) }\end{array}$ & $0.4 \%$ & $5.3 \%$ & $1.2 \%$ \\
\hline
\end{tabular}

Note: BERD are very incomplete, and a rough estimate has been made based of data from the UK, France and a few other European countries. Data for the ICT sector are from Stancik \& Desruelle (2012) and for MCI and all sectors from Eurostat SBS and R\&D statistics. The MCI sector has been defined as the following NACE (rev. 2) classes: J581 Publishing of books, periodicals and other publishing activities; J59 Motion picture, video and television programme production, sound recording and music publishing activities; J60 Programming and broadcasting activities and J639 Other information service activities, in accordance with the OECD definition.

We complement this picture with R\&D data from the 2011 EU industrial R\&D Scoreboard, which includes R\&D investment data, economic and financial data for the 1,000 largest EU and 1,000 largest non-EU R\&D investors in 2010. From the Scoreboard, we extracted a subset of companies, classified by the Scoreboard as media companies, as well as companies from a number of related sectors (Table 3). The Scoreboard data confirms that media companies invest very little in R\&D. Compared to the ICT sector, media companies globally invest about 50 times less. The ICT sector's R\&D investments are, in turn, dominated by US companies. It should be noted however, that some companies that are clearly involved in media and content related innovation, such as Apple and Google, are classified as ICT sector companies. Hence, any media related R\&D 
in such companies would be classified as ICT R\&D in the Scoreboard. This aligns with assumption (3) since the innovative activities in media and content are in this case accounted for as ICT R\&D.

Tables 2 and 3 hint at the possibility that a lot of innovation in the media industry is not captured by the R\&D investment statistics of media companies, thus going in the direction of assumption (2). By the same token, it is difficult to separate $\mathrm{R} \& \mathrm{D}$ investments and investments in other infrastructure/services (assumption 3).

Table 3 Industrial Scoreboard R\&D statistics for ICT, media and total industry (worldwide) in 2010 ( $€$ bn). (Source: Elaborated from the Industrial R\&D Scoreboard IPTS, 2012)

\begin{tabular}{|l|r|r|r|r|r|}
\hline Sector / Sub-sector & EU & Japan & USA & RoW & Total \\
\hline ICT & 28.8 & 34.7 & 66.6 & 26.3 & 156.4 \\
\hline Media & 1.8 & 0.5 & 0.6 & & 3.0 \\
\hline $\begin{array}{c}\text { Total (including non-ICT and } \\
\text { non-media companies) }\end{array}$ & 139.7 & 99.1 & 160.1 & 64.7 & 463.6 \\
\hline
\end{tabular}

Note: It is not relevant to calculate $R \& D$ intensity of the Scoreboard media companies, since only the major R\&D investors are included, not the largest companies in terms of sales.

Finally, a few studies tend to indicate that the first assumption - stating that the MCIs are much less innovative than the ICT industries - is ill-founded. Müller, Rammer, and Trüby (2009) show that creative industries are highly innovative ( $71 \%$ of the creative industries conducted some type of innovation) while the share of enterprises conducting $R \& D$ is much lower $(28 \%)$ in those industries. Their data however apply only to the Austrian case. Roberts (2010) also mentions data for the UK that shows that cultural enterprises there are more reliant on innovation than those in other sectors.

To conclude, this section has given a few arguments that reinforce the idea that R\&D statistics do not properly capture the innovativeness of the MCIs (assumption 2). The next section further addresses the other two hypotheses, namely that media industries are much less innovative than ICT industries (assumption 1), and that the innovative activities in media and content are largely taking place elsewhere (for instance in the ICT sector) (assumption 3). These premises are addressed by applying the typology to a small set of interviews. By doing so, we show that it is not only about if there is media innovation, but also what kind of innovation is being conducted. 


\section{Empirical Exploration: Stakeholders' Perceptions on Media Innovation}

This section provides an empirical exploration of the phenomenon of media innovation. Based on a small-scale round of expert interviews, we aim to give some insights concerning whether or not the media industry is an innovative one, and where does innovation in media come from. This also allows us to show the relevance of typologies and indicators proposed in the second section and to further address hypotheses (1) and (3) introduced in the third section.

The stakeholders were consulted in October 2012. The interviews were semistructured, exploring whether common elements between stakeholders' views on media innovation could be detected. We opted to select stakeholders from three different media industries, namely magazines, newspapers and broadcasting. ${ }^{2}$ All stakeholders are based in Flanders (northern region of Belgium).

Before addressing the main results of the stakeholder consultation, some preliminary remarks should be made. First of all, the stakeholder representatives are to some extent an indicator of perceptions on innovation in the respective industry, but, since this is a first exploration, the findings are by no means representative for the entire industry. The representatives have been chosen because they have very different conceptions of media innovation, so we can show diversity rather than uniformity, which does not exist on the topic at hand. The findings are discussed in line with our proposed typology of media innovations (cf. supra; Table 1).

\section{The Nature of Innovation in the Media Industries}

Following the typology built in section 2, this section shows the media industry is innovative, although the interviewed media representatives do not necessarily consider that all types of innovation are covered by media firms. The results are summarised in Table 4.

2 The following stakeholders were consulted: (1) European Magazine Media Association (EMMA); (2) Vlaamse Nieuwsmedia and (3) Acht TV. EMMA is a non-profit organisation promoting and protecting the interests of European magazine publishers (15,000 publishers publishing over 50,000 titles). Vlaamse Nieuwsmedia (The Flemish Newsmedia) is the association of the Flemish news publishers. Acht TV is a Belgian digital 'niche' TV channel owned by publisher Concentra that mainly broadcasts American and British serials. 
The pre-eminence of content (core) innovation.

All three representatives highlighted the prime importance of core innovation for media professionals. The interviewees expressed this relative to all media sectors that were discussed. Specifically, the magazine representative argued that a major innovative dynamic in the magazine industry is that more and more titles are moving into niche markets, devoting an entire magazine to e.g. horses, wine and tasting, mobile apps or gardening. This holds for small start-ups as well as for established big publishing houses. The creation of niche magazines is core (product) innovation, as a new theme or message is created.

Furthermore, the newspaper representative foresaw that in the upcoming ten to fifteen years, the daily press industry would further evolve towards a more qualitative offer - referring again to core product innovation, with less publications and less (print) circulation. This would lead to a certain scarcity and push prices for newspapers upwards. There would also be more "weekend material", with specialised editions and theme publications.

Finally, the broadcasting representative argued that the Flemish audiovisual media industry is also a pioneer in terms of product innovation with the creation of very high quality programmes and the invention of pioneering, 'top' formats. The remark was made that Flemish quality TV programmes are available to every household and that this could certainly help in ruling out Over-The-Top players that attempt to conquer the market with a mainstream and popular offer. However, the benefits of this core innovation remain marginal because the content is in general not marketable abroad, according to the broadcasting representative.

\section{Innovation in inner form}

Innovation in the inner form is also regarded as important but significantly seen as less driven by the media industry players themselves. In that sense, media players appear to be more reactive than proactive. As one illustration, the newspaper representative put forward inner form innovations related to, for print, newspaper formats, the quality of printing and the colour scheme, and, for digital, the adoption of HTML5. This argumentation dovetails with our third hypothesis, namely that inner form innovations are not driven by MCIs.

\section{Innovation in consumption and media}

For the magazine representative, the most prominent evolution in the print magazine industry was that publishers are trying to maintain their revenue streams by being innovative. They do so by increasingly trying to satisfy their 
advertisers in print using technological innovations (e.g. augmented reality, QRcodes, physically integrating product information). All these new forms of advertising can be seen as consumption/media innovation, because they are part of the process and at the same time of the consumer's experience. This category of innovation deals with how the product is marketed and made available to the consumer. Also, it is directly linked to the product (i.e. magazine) itself and most of all it is perceptible by the consumer and not separable in terms of consumer experience.

Unlike in print, the broadcasting representative stated that the Flemish audiovisual media industry still has a long way to go when compared to the quality level and degree of interactive advertising produced by for instance Sky in the UK. He stated that in the future, the media industry should focus on targeted, customer-tailored advertisements, like on the Internet. Interactive TV applications (e.g. games, SMS and 0900 votes and 'late night' services related to astrology) were also deemed not very innovative.

It seems that stakeholders' perceptions on the degree of innovativeness in consumption and media differ. Whereas highly relevant and pertinent for the magazine representative, especially in terms of new advertising formats, the reasoning of the broadcasting representative points towards the first hypothesis, namely that in terms of innovation in consumption and media, the MCIs are much less innovative than other industries.

\section{Innovation in production and distribution}

The broadcasting representative mentioned that most innovations occurring in the audiovisual sector are those triggered by technology, again referring to our third premise that innovations in production and distribution are driven by other stakeholders. A first example concerns evolutions in video equipment. Twenty years ago, a classical video montage set that allows to assemble TV programmes (e.g. AVID montage cell), cost $€ 60,000$. Nowadays, the same equipment is available for $€ 4,000$. Likewise, cameras used to be very large, heavy and expensive devices that needed to be operated by cameramen. Today, lightweight cameras are available that can be operated by anyone. These innovations in production and distribution also led to new initiatives like YouTube. Nowadays, it is very easy to record a movie with a digicorder, upload it onto the PC, cut out three minutes of film, and place it on YouTube.

As examples of a disruptive innovation in distribution for publishers, the magazine representative mentioned search engines and aggregator apps such as Flipboard and Pulse. These examples show disruption in the form of restructuring how people find the content that they read in the digital environment, and how they get access to content. In our terminology, this disruptive innovation can be defined as process innovation, and production and distribution innovation in 
particular - a 'successful' new means of distributing content. A first disruptive element of content aggregators lies in the fact that publishers are very keen to get the consumer linked to the brand. Obviously, when consumers use search engines or content aggregators, they are leaving the publisher's world, and accordingly, publishers have a hard time getting customer information from that stage onwards. Taking into account that 90 to $95 \%$ of digital revenue for magazine publishers still comes from advertising, if content is aggregated, then magazines cannot monetise it anymore, which is, of course, highly problematic. Additionally, they have no information on reading figures via these access portals. A second disruptive element related to accessing content is that search engines like Google preselect the search results. This is a big issue for content providers that need to be found online and sometimes cannot be found due to the gatekeeping role of such search engines. To partly counteract the problem of disruptive entrants in the market, most magazines in Europe have created their own app. In conclusion, innovations in production and distribution seem to be mainly triggered by technology.

\section{Innovative business models}

In the view of media industry professionals, business model innovation can take several forms. To start with, the entire publishing industry's revenue model increasingly depends on third party funders and contributors (crowdsourcing), as put forward by the magazine representative. This is true both for daily press and magazine titles. The upsurge of such journalistic projects (e.g. based on crowdfunding) and user-generated-content can be labelled as business model innovations. The magazine representative forecasted that media companies would at some point only aggregate and sell the content. Initiatives such as Propublica and the Knight Foundation in the US would finance investigative and qualitative journalism - which is very expensive. Accordingly, media companies would save costs and take results from philanthropically financed research.

A second type of business model innovation concerns multi-platform strategies and cross-subsidisation. The magazine representative stated that print cross-subsidises other new and innovative initiatives, such as digital versions (online and on mobile devices), TV and radio. Indeed, magazines can have their own TV programmes; Der Spiegel in Germany for instance has its own TV show. In the same line, a full audio version of each Economist magazine is available. Besides, there are other initiatives not related to publishing and media (e.g. ecommerce, organisation of events and workshops, search engines). To illustrate, the magazine representative pointed out that in Germany, for Axel Springer, 25\% of total turnover (and 99\% of their digital turnover) is made with their search engine. 
On a related topic, the newspaper representative saw potential in the bundling of different titles combined with e-commerce initiatives. More specifically, he mentioned the current project of the creation of one single sign-on media ID, financed through the Flemish Media Innovation Centre (MiX). ${ }^{3}$ The customer will have a single user and password (with payment details) that can be used to access all publishers' news sites in Flanders.

Also related to the publishing industry and business model innovations, it was noted that in the world of mobile devices, it is easier to monetise content again - something (magazine) publishers previously had difficulties doing on the Internet. For example, the mobile revenue model of the New York Times is quite popular, and seen by magazine publishers as a major role model. One reason for the potential to monetise (mobile and print) magazine content is that the content in the biggest part of the magazine sector is really specialised, and consumers are more likely to pay for that. This certainly is the case for business-to-business magazines. Interestingly, it was mentioned that first movers can deploy their innovations as a brilliant marketing tool to increase brand appeal. However, a very important and crucial message that all stakeholders agreed upon is that in the digital world, there is no sustainable business model for the moment.

To conclude, in this section, we aimed to connect the innovations mentioned by the stakeholders to our typology and hypotheses. Table 4 summarises the findings. It follows loosely the structure of Küng's (2008) questioning (What? Where? How?). To sum up, the interviews revealed that especially core innovation and business model innovation seem important ingredients in media companies' strategies. This is not to say that innovations in inner form, consumption and media, and production and distribution are not prevalent, but these types of innovations seem to be driven more by external players (i.e. mainly ICT and technology companies).

${ }^{3} \mathrm{MiX}$ is a Flemish expertise center that intends to support the media sector when converting innovative concepts and ideas into tangible economical and/or social results. For more information, see: http://www.iminds.be/en/develop-test/mix. 
Table 4. A summary of the findings based on our typology

\begin{tabular}{|c|c|c|c|c|c|}
\hline & \multicolumn{3}{|c|}{ Process } & \multicolumn{2}{|l|}{ Product } \\
\hline & Business Model & $\begin{array}{c}\text { Production \& } \\
\text { Distribution }\end{array}$ & $\begin{array}{c}\text { Consumption \& } \\
\text { Media }\end{array}$ & Inner form & Core \\
\hline $\begin{array}{l}\text { What } \\
\text { innovation is } \\
\text { taking place? }\end{array}$ & $\begin{array}{l}\text { Crowd-funding } \\
\text { User-generated } \\
\text { content } \\
\text { Cross- } \\
\text { subsidisation } \\
\text { Multi-platform } \\
\text { strategies }\end{array}$ & $\begin{array}{l}\begin{array}{l}\text { Video equipment } \\
\text { (montage cells and } \\
\text { cameras) }\end{array} \\
\text { YouTube } \\
\text { Search engines } \\
\text { Aggregator apps }\end{array}$ & $\begin{array}{l}\text { Advertising in print: } \\
\text { Augmented reality, } \\
\text { QR codes, physically } \\
\text { integrating product } \\
\text { information } \\
\text { Advertising on TV: } \\
\text { Interactive advertising } \\
\text { Interactive TV } \\
\text { applications } \\
\text { Second screen } \\
\text { applications }\end{array}$ & $\begin{array}{l}\text { Print: } \\
\text { newspaper } \\
\text { format, } \\
\text { printing } \\
\text { quality, } \\
\text { colour } \\
\text { scheme } \\
\text { Digital: } \\
\text { adoption of } \\
\text { HTML } 5\end{array}$ & $\begin{array}{l}\text { Niche } \\
\text { magazines } \\
\text { More } \\
\text { qualitative } \\
\text { offer in } \\
\text { newspapers } \\
\text { - with more } \\
\text { weekend } \\
\text { material } \\
\text { and } \\
\text { specialised/ } \\
\text { theme } \\
\text { editions } \\
\text { High } \\
\text { quality TV } \\
\text { programs / } \\
\text { formats }\end{array}$ \\
\hline $\begin{array}{l}\text { Who } \\
\text { innovates: } \\
\text { External } \\
\text { players or } \\
\text { media } \\
\text { companies? }\end{array}$ & Both & $\begin{array}{l}\text { Mainly external } \\
\text { players }\end{array}$ & Both & Both & $\begin{array}{l}\text { Media } \\
\text { companies, } \\
\text { often local } \\
\text { ones }\end{array}$ \\
\hline $\begin{array}{l}\text { Is this type of } \\
\text { innovation } \\
\text { triggered by } \\
\text { technology? }\end{array}$ & Not necessarily & Yes & Yes & Yes & $\begin{array}{l}\text { Not } \\
\text { necessarily }\end{array}$ \\
\hline
\end{tabular}




\section{Who Innovates? The Risk of Innovation Being Led from Outside the Media Sector}

While the previous subsection indicated that innovation is in effect taking place in the media sector, it needs to be questioned who the actual innovators are, and what steers innovation. Low innovation expenses on media are to a certain degree explained by the fact that part of innovation is not assessed by common innovation measurement of R\&D expenses (cf. hypothesis 2). Another explanation may be that innovation in media is done by non-media players, in particular ICT-players (cf. hypothesis 3).

The magazine representative validates the finding of low $R \& D$ spending in the MCI, arguing that, for many years, publishers did not invest in R\&D because it was not necessary for them to survive. The situation however has changed due to digitisation; publishers need to invest, at least more than before. In addition, the newspaper representative stipulates that there is almost no investment in Research but investments in Development are considerable. For example, it is mentioned that 30 to $35 \%$ of the costs are incurred to develop new applications.

The interviewed stakeholders all tend to confirm that innovation in the media industry is mainly technologically driven. Technology forces the media industry to embrace it and spurs innovation. According to the magazine representative, this form of innovation can be very disruptive (cf. supra, the example of search engines and aggregator apps). It does not necessarily mean that all innovations are technological (e.g. new device, new software) but they are often derived or made possible by technology. For example, the multiplication of niche magazines discussed in the previous section is made possible by the reduction in printing costs enabled notably by technology. But it would be incorrect to consider that this multiplication stems from technology alone.

Furthermore, the newspaper representative admits that innovations in the publishing industry are generally triggered by third parties, e.g. the 'Gopress' initiative was triggered by Amazon. Instead of donating 30\% of the revenue and consumer details to Amazon, Belgian publishers decided to create their own distribution platform to sell digital versions (both online and mobile) of newspapers and magazines.

In the same way, the broadcasting representative argues that the majority of the innovations that are occurring in the audiovisual sector are triggered by technology (cf. also Küng's (2008) statement that new technologies challenge the media sector and force media organisations to make use of them). Interestingly, in the beginning the audiovisual industry generally opposes to technological innovation, from colour, digital or HD television to second screen applications. Technological innovation is forced upon the audiovisual media industry in such a way that they have to adapt to it. Accordingly, they leave room for external (ICT) players to lead innovation in the media sector. 
To conclude, the interviewees debated the capacity of current innovation policies in Flanders to trigger innovation. Whereas the newspaper representative believes that all media companies in Flanders are eager to work together in research consortia like $\mathrm{MiX}$, the broadcasting representative claims that media companies will most certainly not cooperate in terms of creating new innovative products or services because there is too much competition. Therefore in his opinion, the Flemish government would promote innovation in a far more efficient way by investing more money in fundamental research, or by importing the outcomes of such research. In terms of content production and subsidies, it is mentioned that the tax shelter ${ }^{4}$ and $\mathrm{VAF}^{5}$ are two organisations that have dramatically improved the content production in Flanders.

\section{Conclusion and Implications for Further Research}

Media innovation is slowly gaining attention in the academic community, policy circles and among practitioners. However, the concept is still poorly defined and not well understood. That is why, in this paper, we have explored the concept of media innovation in the literature, in statistics, in policy and in practice.

We have argued that traditional definitions often overlook creative industries due to the exclusion of content-related innovation. Problematically, such innovations are typically underestimated when metrics of $R \& D$ and patents are applied (Abreu et al., 2010). Actually, while innovation consists in something new being put into practical use, thus including aesthetic, informational or any other content-related innovation - the habit among policy makers and practitioner is to value innovation based on functional, technical and performance improvement.

This bias is reflected in innovation policy and its application to media, it became clear that innovation policy is biased towards the STEM sector (science, technology, engineering and mathematics) (Jaaniste, 2009). Moreover, evidence shows that the search for a well-balanced innovation policy mix and the appropriate indicators proves hard for policy makers.

Indeed, existing innovation statistics, as far as they are possible to apply to the media sector, show very low levels of innovative activity by media companies, at least when measured by $R \& D$ data. Still there are indications that the media sector is quite innovative, if the concept and measurement are broadened. As

\footnotetext{
${ }^{4}$ The Belgian Tax Shelter encourages the production of European audiovisual works by giving a fiscal incentive to companies that invest in them. For more information, see: http://www.belgiumfilm.be/tax-shelter/.

${ }^{5}$ The Flanders Audiovisual Fund (VAF) supports audiovisual production in Flanders. For more information, see: http://www.vaf.be/taal/en/.
} 
such, it would be wise to develop tools for better measurement of media innovation altogether.

A first step in this direction has been taken in this paper. Based on the traditional distinction between product and process innovation, we have proposed a novel typology of innovation in the media sector, based on five categories: business model, production and distribution, consumption and media, inner form and core.

We then compared R\&D expenditures for the MCI and ICT industries based on two different sources (BERD and Industrial R\&D Scoreboard data), which lead to a number of hypotheses, namely that (1) the MCIs are much less innovative than the ICT industries; (2) that R\&D statistics do not properly capture the innovativeness of the MCIs; and (3) that the innovative activities in media and content are largely taking place elsewhere. Whereas the statistical indicators point towards the second explanation, the expert interviews revealed that there is a case for hypotheses 1 and 3 as well.

First of all, it was shown that all forms of innovation defined in our typology exist in the media field, but not with the same importance. The most important ones from the media industries' point of view seems to be the innovations related to the product, notably concerning the core (e.g. creation of new types of TV shows) and the business model. This is not to say that innovations in inner form, consumption and media, and production and distribution are not prevalent, but these types of innovations seem to be driven more by external players (i.e. mainly ICT and technology companies) and at best the media industries try to adapt to the rapidly changing technological context. Hence, technology forces the media industry to embrace it and spurs innovation, which, in a way, is a circular argument.

This said, two remarks are in place. Firstly, technological innovations may foster other types of innovation. For instance, the technological evolutions in video equipment improved the way of filming a TV programme and lead to new initiatives like Youtube. As a second remark, the media industry is often initially reluctant to change, but because technology is so dominant, the sector eventually has to embrace it. This is most certainly the case in the audiovisual media industry, where many technological innovations are pushed into the market by the technological partners, such as e.g. smart TV, connected TV and second screen applications.

In this context, implications in terms of policy cannot be straightforward. Innovation policy does not pay a great deal of attention to media because large parts of the creative activity taking place in the media and content sector are not defined as innovation. Conversely, media policy is more concerned with issues such as pluralism and diversity and therefore traditionally does not frame its policies in terms of innovation. A better alignment of media and innovation policies might therefore be advocated. 
In conclusion, since the paper has shown that media innovation is far from understood, we recommend more research dealing with a systematic tracking of media innovation, notably in terms of statistics, resulting in a more holistic view taking all types of innovation and their dependencies into consideration. As suggestions for future research, we plan to apply our typology to more innovations in different media industries (e.g. radio, videogames, audiovisual) in order to further refine our assumptions on (1) the importance of core and business model innovation for media industries and (2) other types of innovation being mainly driven by ICT and technology companies.

\section{References}

Abreu, M., Grinevich, V., Kitson, M. \& Savona, M. (2010). Policies to enhance the hidden innovation in services: Evidence and lessons from the UK. Service Industries Journal, 30(1), 99-118.

Ballon, P. (2007). Business modelling revisited: the configuration of control and value. Info 9(5), 6-19.

Castañer, X. \& Campos, L. (2002). The determinants of artistic innovation:

Bringing in the role of organizations. Journal of Cultural Economics, 26(1), 29-52.

Caves, R. E. (2000). Creative industries: Contracts between art and commerce. Cambridge: Harvard University Press.

Cave, J. \& Frinking, E. (2007). Public Procurement for R\&D. University of Warwick. [online]. Available at

$<$ http://www2.warwick.ac.uk/fac/soc/economics/staff/academic/cave/publications /pp_for_rd.pdf $>$ (Last accessed 20 September 2013).

Dogruel, L. (2013). Opening the black box - Conceptualizing of media innovation. In A. Krumsvik \& T. Storsul (Eds.), Media Innovations A Mutidisciplinary Study of Change (pp. 29-44). Nordicom: Göteborg.

Donders, K., Ballon, P., Ranaivoson, H., Lindmark, S., Evens, T., Rucic H. \& Hyytinen, K. (2011). Naar een ecosysteem-model voor onderzoek en innovatie rond audiovisuele consumptie in Vlaanderen. (Towards an ecosystem model for research and innovation on audiovisual consumption in Flanders. Deliverable 2. Desirable and feasible scenarios for collaborative innovation in the Flemish media sector), Brussel / Gent: iMinds-SMIT, VUB / MICT, UGent.

EU Media Futures Forum (2012). Fast-forward Europe. Final report for European Commission, Vice-President Neelie Kroes. September 2012. Available at $<$ http://ec.europa.eu/information_society/media_taskforce/pluralism/forum/in dex_en.htm $>$ (Last accessed 18 September 2013).

European Commission (2010). A rationale for action. Commission staff working document accompanying European Commission (2010b). 
Freeman, C. \& Soete, L. (1997). The economics of industrial innovation, 3rd ed. Pinter: London.

Handke, C. (2010). The creative destruction of copyright - Innovation in the record industry and digital copying. PhD Thesis, Erasmus Universiteit Rotterdam, Rotterdam.

IPTS (2012). A series of studies published by IPTS. Available at $<$ http://is.jrc.ec.europa.eu/pages/ISG/MCI.html $>$ (Last accessed 2 August 2013).

Jaaniste, L. (2009). Placing the creative sector within innovation: The full gamut. Innovation: Management, Policy \& Practice, 11(2), 215-229.

Kamprath, M., \& Mietzner, D. (2009). The nature of radical media innovation Insights from an explorative study. 2nd ISPIM Innovation Symposium "Stimulating recovery - The role of innovation management", New York.

Kline, S.J. \& Rosenberg, N. (1986). An overview of innovation. In R. Landau \& N. Rosenberg (Eds.), The positive sum strategy: Harnessing technology for economic growth (pp. 275-305). Washington, DC: National Academy Press.

Köhler, L. (2005). Produktinnovation in der medienindustrie:

Organisationskonzepte auf der basis von produktplattformen (Product innovation in the media industry: organizational concepts based on product platforms). DUV Gabler Edition Wissenschaft, Wiesbaden.

Küng, L. (2008). Innovation and Creativity in the Media Industry: What? Where? How?. In C. Dal Zotto \& H. van Kranenburg (Eds.), Management and Innovation in the Media Industry (pp.3-13). Cheltenham, UK: Edward Elgar.

Lundvall, B-Å. \& Borrás, S. (2005). Science, technology, and innovation policy. In J. Fagerberg, D.C. Mowery \& R.R. Nelson (Eds.), The Oxford handbook of innovation (pp. 599-631). Oxford University Press.

Martin, R. (2009). The Design of Business: Why Design Thinking is the Next Competitive Advantage, Harvard Business School Press.

Müller, K., Rammer, C. \& Trüby, J. (2009). The role of creative industries in industrial innovation. Innovation: Management, Policy \& Practice, 11(2), 148-168. Available at: $<$ http://dx.doi.org/10.5172/impp.11.2.148> (Last accessed 2 July 2013).

NESTA (2006). The innovation gap: Why policy needs to reflect the reality of innovation in the UK. London: NESTA.

NESTA (2007). Hidden innovation: How innovation happens in six 'low innovation' sectors. London: NESTA. Available at: $<$ http://www.nesta.org.uk/assets/Uploads/pdf/ResearchReport/hidden_innovation_report_NESTA.pdf $>$ (Last accessed 20 May 2013).

NESTA (2009b). Soft innovation towards a more complete picture of innovative change. Research report, July 2009. Available at $<$ http://www.nesta.org.uk/library/documents/Report $\% 2022 \% 20$ \%20Soft\%20Innovation\%20v9.pdf $>$ (Last accessed 21 September 2013). 
OECD (1997). Oslo manual: Proposed guidelines for collecting and interpreting technological innovation data. 2nd Edition, OECD, Paris. Available at http://www.oecd.org/science/inno/2367580.pdf> (Last accessed 23 January 2013).

OECD (2002). Proposed standard practice for surveys on Research and experimental Development. Frascati Manual, OECD, Paris.

OECD (2005). Oslo manual: Guidelines for collecting and interpreting innovation data. 3rd Edition, OECD, Paris. Available at $<$ http://www.oecd.org/document/33/0,3746,en_2649_34273_35595607_1_1 1 1,00.html $>$ (Last accessed 23 September 2013).

OECD (2009). Guide to measuring the information society, OECD, Paris.

OECD (2010). Science, technology and industry outlook 2010.

James Roberts (2010), "Beyond content: innovation in the television industry", European Media Management Education Association.

Schmookler, J. (1966). Invention and economic growth. Cambridge, MA: Harvard University Press.

Schumpeter, J. (1942). Capitalism, socialism and democracy. New York: Harper and Brothers.

Schweitzer, T. S. (2003). Managing interactions between technological and stylistic innovation in the media industries. Technology Analysis \& Strategic Management, 15(1), 19-41.

Stancik, J. \& Desruelle, P. (2012) The 2012 PRDEICT report: An analysis of ICT R\&D in the EU and beyond. JRC scientific and policy reports, EN 25539 EN. Available at $<$ ftp://ftp.jrc.es/pub/EURdoc/JRC75513.pdf $>$ (Last accessed June 28 2013).

Stoneman, P. (2010). Soft innovation. Economics, product aesthetics, and the creative industries. Oxford University Press: Oxford. 